\title{
IDENTIFICATION OF COMPETITIVE ADVANTAGES - CONDITION FOR A SUCCESSFUL APPEARANCE OF INSURANCE COMPANIES IN THE INSURANCE MARKET
}

\author{
Katerina Angelevska-Najdeska ${ }^{245}$ \\ https://doi.org/10.31410/itema.2018.640
}

\begin{abstract}
The success of the company to preserve consumers consists of better understanding of consumer's needs and theirs buying processes. In order to build a good business and profitable relationships with their customers, the insurance company should first analyze and understand customer needs and offer a product as a set of insurance services with greater value. When the insurance company differentiates its offer with superior value in the selected target markets, then it acquires a competitive advantage. However, achieving strong market positions require maximum professionalism in the performance and fulfillment of the promise to the customers. Namely, if the insurance company places its product on the market as an offer with the best quality and service, then it must transfer the promised quality and service. Therefore, the insurance company chooses a marketing offer that will be different from the marketing offer of the competition, in order to offer to their consumers' greater value than the one offered by competitors.

In order to find the points of differentiation, the marketing department in the insurance company should investigate the behavior of consumers towards its products or insurance services. The insurance company that seriously approaches the relationship and communication with its customers finds different ways to differentiate in contact with customers.

Selection of the market is one of the most important decisions that the insurance company should make in building the development strategy. The selection of the market on which the company wants to perform conditions the process of its development is very important, and any prematurely taken steps can cause negative consequences in the future. Decisions to enter the market based on wrong assumptions, poorly executed and badly timed, may have serious negative consequences on the company's development.

When an insurance company makes the decision to select a particular market to perform, management must consider all factors that affect that market. The company should make a detailed analysis, paying particular attention to the impact that such a choice will have on the development strategy.
\end{abstract}

Keywords: competitive advantages, insurance companies, insurance services, insurance market

\section{INTRODUCTION}

$\mathrm{W}$ hen an insurance company decides to select a particular market in which it intends to perform, management must consider all the factors that influence that market. The company should make a detailed analysis, paying particular attention to the impact that such a choice will have on the development strategy.

\footnotetext{
${ }^{245}$ Faculty of Tourism and Hospitality, Kej Makedonija 95-Ohrid, Macedonia
} 
Insurance companies must make the right decision about how and which of their products and services they will place on the selected segments of the market. The needs and preferences of consumers on the target markets must be materialized in the form of a specific marketing mix, in which price, promotional activities and distribution have to be considered. Extremely important is how consumers perceive the service as a treat compared to competitive tender.

In order to build good business and profitable relationships with its customers, the insurance company should first analyze and understand the needs of customers and offer them a product as a set of insurance services with greater value than competitors.

When the insurance company will be differentiated as the carrier of the superior value of the selected target markets, then it gains a competitive advantage. But, achieving solid market positions require maximum performance and professionalism in fulfilling promises to customers. The insurance company chooses a marketing offer that will differ from the marketing offer of competition, in order to offer consumers more value than the one offered by competitors.

\section{DIFFERENTIATION OF THE OFFER OF INSURANCE SERVICES FOR ACHIEVING COMPETITIVE ADVANTAGE OF THE COMPANY}

Sustainable competitive advantage is based on the company's basic comparative advantages, specific capabilities and capital, that is, in the efficient management of the process of offering services, the company's ability to manage distribution channels, etc. [1]

The insurance company or its offer on the market can be differentiated by product (insurance services), distribution channels, human resources and image.

Product differentiation is a process that is continuous. When it comes to classic products, a company can have an opportunity for smaller or larger differentiations, i.e. low or highly differentiated products. Accordingly, companies will be able to separate their products to the attributes such as endurance, durability, security or reparability. But when it comes to companies that offer services like insurance companies, then the differentiation refers to speed, convenience or prudence in offering services, for example, the quickest resolution of damage, the fastest payout, the greatest discount for loyal customers.

Insurance companies that are differentiated on the insurance market through distribution channels, gain competitive advantage through the way they organize coverage of the market (through sales agents, brokers, representative offices in several locations, on-line sale, and all that in order to be more accessible to customers), mobility and adaptability to customer and efficiency, or the performance of their distribution channel. Successful differentiation of the insurance company and the services offered depends on the design of distribution channels. This is achieved by analyzing consumer needs, establishing channel objectives and identifying and evaluating major alternatives. [2]

Also, insurance companies can gain a strong competitive advantage through differentiation of human resources. In fact, it actually means that the insurance company will pay special attention to the selection of human resources to engage and train or hire from those of the competition. Gaining a competitive advantage based on the human resources requires that the insurance company carefully selects employees who are in contact with consumers and conducts continuous trainings for their upgrading. 
From the perspective of consumers, contact with the service staff is probably the most important aspect of the service. From the point of view of the company, however, the quality of the service and the way it is offered or delivered by the human resources that come in direct contact with customers can be an important source of differentiation and the possibility of achieving a competitive advantage due to the following reasons: [3]

$>$ They are an essential part of the product - most often the human resources in the insurance companies that come in direct contact with the customer are the most visible element of the service and significantly determine its quality.

$>$ They are a service company - the human resources in insurance companies that come in direct contact with customers represent the company, and from the point of view of customers they are actually the company.

$>$ They are the brand - the human resources in insurance companies that come in direct contact with customers and the service they offer are often an essential part of the brand, and they determine whether it is offered or delivered what the brand promises.

$>$ They affect sales - the human resources in insurance companies that come in direct contact with customers are often a key factor in generating sales, cross-selling and upgraded sales.

$>$ They determine productivity - the human resources in insurance companies that come in direct contact with customers have a strong impact on the productivity of the insurance company's performance.

Differentiation of the insurance company on the market for gaining a competitive advantage can be achieved also through the company's image or brand. Even when competitive offers of insurance companies look the same, however, customers can see the difference based on the company's image or brand. The image or brand of a company should reflect the characteristic advantages and position of the insurance company and its product on the market. Developing a powerful and distinctive image requires creativity and hard work. Selected symbols, characters, or other elements must communicate through an advertisement that transfers the identity of the company or brand.

When it comes to determining the convenience, Kotler emphasizes two key issues: [4]

$\checkmark$ - Which differences to propagate (point out) - in this case, insurance companies need to analyze the comparative advantages and disadvantages and to identify differences that should be displayed. In determining the competitive position, several basic characteristics can be distinguished, by which companies can adequately position themselves in the target insurance market,

$\checkmark$ - How many of the differences stand out - in the context of this issue, very important point is to decide how differences should be propagated - one, two, several or all. If the insurance company owns an original (unique) attribute, it can be positioned as number one in the insurance market in relation to that attribute. If it has several, less specific attributes, then it will have to find a separate free market space within the target segment.

If an insurance company determines several differentiations as potential competitive advantages, then it must decide how many and which of the determined competitive advantages will be promoted and upon which to build its positioning strategy. Some companies think that they need to aggressively promote only one advantage (attribute) in the target market.

It's best when the company develops a unique sales proposal for each brand and forces it. Each brand should choose attributes and advertise itself as "number one" with that attribute. So, customers will easily memorize this attribute, especially in a society with great communication. 
A company that chooses one of these positions and will constantly report it, is likely to become known and remembered by it.

The choice of competitive advantages based on which the product or service will be positioned is a complex issue, but these elections are critical to success. The company must carefully select ways to differentiate itself from competitors, since not all brand differences are significant or cost-effective, and not every difference makes a good difference in terms of the costs and benefits that they cause.

\section{DECISIONS ON THE SELECTION OF NEW MARKETS - TIME AND MANNER OF ENTRY}

Adopting strategic perspectives related to market choice decisions indicate whether the insurance company considers such decisions to be important for designing an effective strategy. They determine the ground on which the company competes, to which companies they compete, and the level of investment or resources needed to compete on a particular market. Such a market entry perspective fosters the need to analyze not only the characteristics of a particular market, but also the strengths and weaknesses of the company in relation to its competitors. As a result, the level of investments and the determination of the resources required for the successful development of the company is determined. Market characteristics, such as the size and growth rate and their interconnection, determine the market's attractiveness to the management of the company, as well as the expected risks associated with entry into that market. However, when choosing a market, it is necessary for managers to explore and analyze the competition and the position of competitors on the market, as it is of great importance in making decisions about the choice of a target market.

The attitudes of the insurance company's management whether and how much risk they will accept, influence the decision on the level of resources that they can target for aggressive expansion on the market. Attitudes, however, against the risk associated with the environment, influence the choice of the market on which the company decides to perform. Risk avoiding companies strive to avoid markets that have a high degree of political, financial, and economic risk, that is, most often, so these companies apply a non-aggressive competitive strategy. Other companies are significantly more aggressive and determined to allocate more resources for developmental expansion.

Decisions to enter the market require the engagement of various resources to achieve that goal. The financial resources are needed to conduct all initial market research to undertake appropriate promotional activities to establish relationships with distributors and adaptation of products (insurance services). The insurance company should implement a financial strategy that will provide an adequate financial structure in order to achieve the set goals, but also to achieve a competitive advantage through lower spending on the engagement of financial resources. [5] Also, management should allocate a certain amount of time for making certain decisions for the selected market and for developing a competitive strategy, as well as for familiarization with the market environment of the selected market.

The company's willingness to direct resources to other emerging markets is often influenced by the perception of risk in those markets. Mostly emerging markets are associated with higher risk and therefore require caution in directing resources to those markets. Thus, with the acquisition of market experience, the risk expectations are reduced, and the willingness to engage resources increases. 
The degree of readiness of management to hire certain resources for the selected market influences the choice of strategy for market entry. Simultaneous entry to multiple markets requires the engagement of significantly larger financial and managerial resources than if the company has chosen an entry-only strategy for one market. [6] Also, the company should analyze the environment of the selected market, because management will need to determine the company's ability to work in such an environment. Important for the insurance company is also to adapt its products (insurance services) and strategies to the specific characteristics of the chosen market.

The evaluation of the characteristics of the market is actually a key factor in making the decision about the selection of the market. The company that chooses a particular strategy must pay particular attention to the interdependence, the possibilities of interconnection and similarities in certain markets.

The magnitude and degree of growth are key indicators of market attractiveness. Namely, winning the market is easier when it comes to markets that have a high growth rate. However, on the other hand, large markets and those with high growth rate require hiring a greater volume of resources, which in turn affects the level of risk. The size and growth rate of the market are not always interconnected.

In addition to the size and growth rate of the market, the insurance company should also take into account the interconnectedness of certain markets, in terms of the similarities and degree of market integration in certain markets. Similar demand characteristics and market infrastructure, influence the choice of strategy or similar strategies that can be applied to markets with similar characteristics. However, apart from the similarities, the company must also analyze the differences in the marketing infrastructure that relate to the media network, the distribution system and advertising. These factors may facilitate or impede the application of similar strategies in different markets.

The nature of the competitive environment is another key factor that influences the decision to choose the market. Often, companies explore market competition by segment, however, it is not uncommon for research to be done on the whole market. Rather static approach to competition analysis should consider the dynamics of the competitive strategy and its impact on decisions when choosing a target market. The more information the company can get for its competitors, the better it can formulate and implement effective strategies. [7]

The structure of the activity is a key determinant in the behavior of the competition. The degree of concentration or market segmentation is also a key determinant when it comes to entering that market if the company's decision to enter a market is conditioned by competition decisions. [8] If the structure of the activity is such that the small and medium-sized enterprises operate in the largest percentage of the market, then the company has more freedom in the selection of the market, and the influence of the competition on the company is not great. On the other hand, if big companies are represented on the market, then every company that will perform on the particular market must carefully analyze the behavior of competing companies for a longer period of time.

Where there is a relatively limited number of companies that dominate in a particular activity, front strategy of competitors and the possible effects of competing companies are key factors in making decisions in a particular market. The company can decide to perform on a neutral 
market where there is no big competition, or to open up new markets where competition is becoming increasingly stronger in many activities.

The dynamics of decision-making when choosing a market emphasizes the importance of examining the expansion strategy. It is also possible to perceive the reactions of competing companies about the decision to choose a particular market.

This underlines the need to follow competitive decision makers' models of competition and their potential impact on the position of competitors. The rapid expansion of multiple markets increases the competitive advantage, whether it is based on the production or service process, or marketing.

Entrance to the competition in key markets may hinder the entrance of other competing firms, or to make these markets less attractive. Competition reactions to the company's entry into the market should be considered, as these reactions depend on the strategic goals associated with market entry decisions and the competitive position of larger competitors.

\section{CONCLUSION}

The choice of competitive advantages on the basis of which the product or service will be positioned is a complex issue, yet such choices are crucial to success. Therefore, it should be taken into account whether the difference provides a high value contribution to the target customer in comparison with the competition, whether the difference is superior to other ways in which consumers can receive the same benefit, whether the difference is recognizable and visible to customers, whether the competitors can easily copy the difference, whether customers can afford to pay the difference and whether the company can be profitable or not.

The decision on selection of the target market is the sublimation of internal advantages that the insurance company has, and the favorable market opportunities being offered. Decisions to enter the market should not only be based on assessment of the attractiveness of the market, Company should treat these decisions as a key component of competitive strategy, taking into account the strategic importance of these decisions.

\section{REFERENCES}

[1] Douglas S., Craig S., Globalna marketing strategija, Grmeč, Beograd, 1997, p. 118

[2] Kotler P., Keller K., Marketing Management, Pearson Education, Prentice Hall, 2009, p. 456

[3] Lovelock, C., Witrz, J., Services Marketing, 7th Edition, Pearson Education, Inc, Prentice Hall, 2011, p. 285

[4] Kotler P., Marketing Management: Analysis, Planning and Control, Englewood Cliffs, N.J.: Prentice Hall, 1988, p. 383

[5] Šuklev B., Drakulesvki Lj., Strategic Management, Faculty of Economics, Skopje, 1996, p. 150

[6] Doyle P., y Gidengil, Z.B., A Strategic Approach to International Market Selection, Proceedings of the American Marketing Association (AMA), Chicago, 1977, p. 359

[7] David. Fred R., Strategic Management, Third edition, Merrill Publishing Company, New York, 1989, p. 133

[8] Davidson, William, H., Global Strategic Management, New York: John Wiley and Sons, 1982, taken from Douglas S., Craig S., Globalna marketing strategija, Grmeč, Beograd, 1997 год., стр. 141 